\title{
Patterns of glass sponge (Porifera, Hexactinellida) distribution in coastal waters of British Columbia, Canada
}

\author{
S. P. Leys ${ }^{1, *}$, K. Wilson ${ }^{2}$, C. Holeton ${ }^{2}$, H. M. Reiswig ${ }^{2}$, W. C. Austin ${ }^{3}$, V. Tunnicliffe ${ }^{2}$ \\ ${ }^{1}$ Department of Biological Sciences, CW 405, University of Alberta, Edmonton, Alberta T6G 2E9, Canada \\ ${ }^{2}$ Department of Biology, University of Victoria, Victoria, British Columbia V8W 3N5, Canada \\ ${ }^{3}$ Khoyatan Marine Laboratory, Sidney, British Columbia V8L 4X3, Canada
}

\begin{abstract}
Glass sponges are enigmatic members of the deep-sea fauna that inhabit shallow waters in only a few locations world-wide. In order to understand what factors influence the distribution of glass sponges, patterns of distribution and abundance of reef and non-reef forming hexactinellids in fjords of British Columbia, Canada, were analyzed from photographs and transcripts recorded on dives undertaken by the 'Pisces IV' manned submersible during the 1980s. Hexactinellids are widely distributed throughout all fjords from 16 to $650 \mathrm{~m}$ depths, and in some fjords abundances reach 240 individuals in $10 \mathrm{~m}^{2}$. In all fjords hexactinellids were most abundant at depths of 20 to $260 \mathrm{~m}$, even where water depths exceeded $500 \mathrm{~m}$. Glass sponges were rare in regions of inlets where oxygen levels fall below $2 \mathrm{ml} \mathrm{l}^{-1}$, or in areas of high sediment deposition. Highest abundances coincided with water conditions of high dissolved silicate, low light, temperatures between 9 and $10^{\circ} \mathrm{C}$ and low suspended sediments. Extensive glass sponge skeletons in the inner basin of Howe Sound reflect past stress in this fjord that may include oxygen deficit, sediment loading from a mine and contamination from industrial sites. The observations from 'Pisces IV' suggest that glass sponges may be sentinel species for current and past seawater conditions in coastal British Columbia.
\end{abstract}

KEY WORDS: Glass sponges $\cdot$ Hexactinellida $\cdot$ Fjords $\cdot$ Silica $\cdot$ Sponge reefs

\section{INTRODUCTION}

Glass sponges (Porifera: Hexactinellida) are remarkable animals. They produce a skeleton of nearly pure glass $\left(\mathrm{SiO}_{2}\right)$ that can be $>1 \mathrm{~m}$ in height and breadth; the major component of their soft tissue is a giant multinucleate syncytium, and although they have no nerves, they can propagate electrical signals through the whole organism to control their feeding current (Reiswig 1979, Mackie \& Singla 1983, Leys \& Mackie 1997, Leys 2003, Sandford 2003). These unusual features may reflect the ancient heritage of hexactinellids as the descendants of the earliest metazoans (Müller 2001), but it is also likely that they are adaptations of the sponges to their preferred deep-water habitat. Glass sponges typically live in deep oceans (500 to $3000 \mathrm{~m}$ ) world wide. There are only 4 locations where glass sponges are found shallower than $50 \mathrm{~m}$ : Antarctica, fjords of southern New Zealand, some caves in the Mediterranean, and the coastal waters of the northwest Pacific.

The great difference between North America's glass sponge communities and those of all other oceans is the presence of large numbers of dictyonine, reefbuilding sponges. Their skeleton consists of a rigid, 3-dimensional framework that remains long after the sponge has died, forming a substrate for future generations of sponges. At least 7 reefs of hexactinellids have recently been discovered at 165 to $240 \mathrm{~m}$ in Hecate Strait and the Strait of Georgia, British Columbia. The reefs are up to $19 \mathrm{~m}$ high and can cover 2 to $10 \mathrm{~km}^{2}$ (Conway et al. 2001, Krautter et al. 2001). The reefs are formed by 3 principal reef-forming species, but are also home to 4 non-reef forming species, and a host of 
other invertebrates (Krautter et al. 2001). Although vast reefs of glass sponges were common 200 million years ago during the Jurassic, when they colonized the margins of the Tethys Sea (Ghiold 1991, Krautter et al. 2001), today the Canadian sponge reefs are the only ones known to exist. What limits the distribution of glass sponges globally, and reef-forming glass sponges locally, is not yet clear.

Deep-water populations of non-reef forming glass sponges in Antarctica and in the North Atlantic have been found to play an important role in increasing local biodiversity by offering a substrate for the settlement of other invertebrates (Barthel \& Gutt 1992, Bett $\&$ Rice 1992). Because of their immense size the sponge reefs are also known to have an impact on fish and invertebrate abundances (Jamieson \& Chew 2002), as do the deep sea coral reefs in the North Atlantic (Husebø et al. 2002). The regions surrounding both types of reef have been targeted by trawl fisheries, resulting in devastating damage (Conway et al. 2001, Hall-Spencer et al. 2002). Considering the peculiar nature of glass sponges, and their restricted global distribution, an understanding of the oceanographic features of the shallow-water habitats that are conducive to the growth and welfare of glass sponges is not only of academic interest, but would be useful for environmental policy makers.

The shallow-water populations on Canada's Pacific coast are readily accessible to study by both SCUBA and manned and unmanned submersibles. As a first step to understanding the habitat requirements of glass sponges, we have carried out an analysis of the distribution and abundance of glass sponges from photographs and transcripts recorded on numerous dives undertaken by the manned submersible 'Pisces IV' in the inlets of British Columbia. In this paper we assess differences in the patterns of vertical and horizontal distribution of reef and non-reef forming sponges between fjords, and seek correlations with biological and chemical oceanographic features of the fjord habitats in order to identify the conditions required for glass sponge growth.

\section{MATERIALS AND METHODS}

Underwater observations. Photographs of hexactinellid sponges were taken in 2 ways using the 'Pisces IV' submersible: with a Pentax F camera shooting through the submersible window and with a Photosea 2000 camera mounted on the brow of the submersible. Additional images of the sponges were captured with a Sony DSC F707 camera mounted on the remotely operated vehicle 'ROPOS' in Barkley Sound in 2002 and 2003.
Because there is considerable morphological variability within individual species, and morphological similarity between species of hexactinellids, identification of individual specimens from photographs or video-recordings is not always accurate. In many instances, it is possible only to determine whether the sponge has a loose or fused skeletal structure. Thus, sponges were distinguished only to the ordinal level (Lyssacinosa and Hexactinosa, hereafter referred to as 'lyssacine' and 'dictyonine'). Furthermore, because poor visibility in coastal waters (often only 3 to $5 \mathrm{~m}$ ) can compromise correct identification, the present study is based only on transcripts of those dives on which one of 3 experts $-V$. Tunnicliffe, H. M. Reiswig, or W. C. Austin-were divers.

Dive locations and analysis of transcripts and photographs. In all, these divers carried out 190 'Pisces' dives to explore inlets on the south, central and north coasts of mainland British Columbia, and on the west side of Vancouver Island (Fig. 1); 59 dives returned complete records, photographic and/or written.

Many observations derive from 4 inlets-Jervis Inlet (JI), Knight Inlet (KI), Howe Sound (HS) and Saanich Inlet (SI). Dives usually consisted of a descent to the bottom followed by a slow ascent up the fjord wall for data collection. Location and numbers of sponges observed during dives in each inlet were extracted from records. In 3 inlets (JI, HS and SI), photographs were taken at 2 to $5 \mathrm{~m}$ intervals along vertical transects. At some depths many photographs were taken, while at others the submersible could not make a safe approach to the wall. Those dives with the most complete photographic coverage were selected for a quantitative analysis of the distribution and abundance of both types of sponge as a function of depth ('Pisces' Dives JI 849, 986, 989, 1219; HS 1009, 1011, 1217, 1575; SI 884, 942, 1385). The depth, number and type of sponges present, morphology of sponges, slope of the substrate, and type of substrate were recorded for each photograph. The area covered by the photograph was allocated to 1 of 4 categories: $0-0.25,0.25-0.5,0.5-1.0$ and $1.0-2.0 \mathrm{~m}^{2}$. Area was calculated by the determinate size of other animals (i.e. brachiopods) in the image or the presence of an extended scale. The average number of small $(<10 \mathrm{~cm})$, medium $(10-25 \mathrm{~cm})$ and large $(>25 \mathrm{~cm})$ sponges of lyssacine and dictyonine morphologies in $20 \mathrm{~m}$ depth intervals was calculated. The area covered by each photograph was taken into account to generate a weighted average; the number of sponges in each photograph was multiplied by the area of the photograph and an average was taken of the counts per area photographed. Where possible, a description of substrate and slope association of both types of sponge was based on these photographs. 

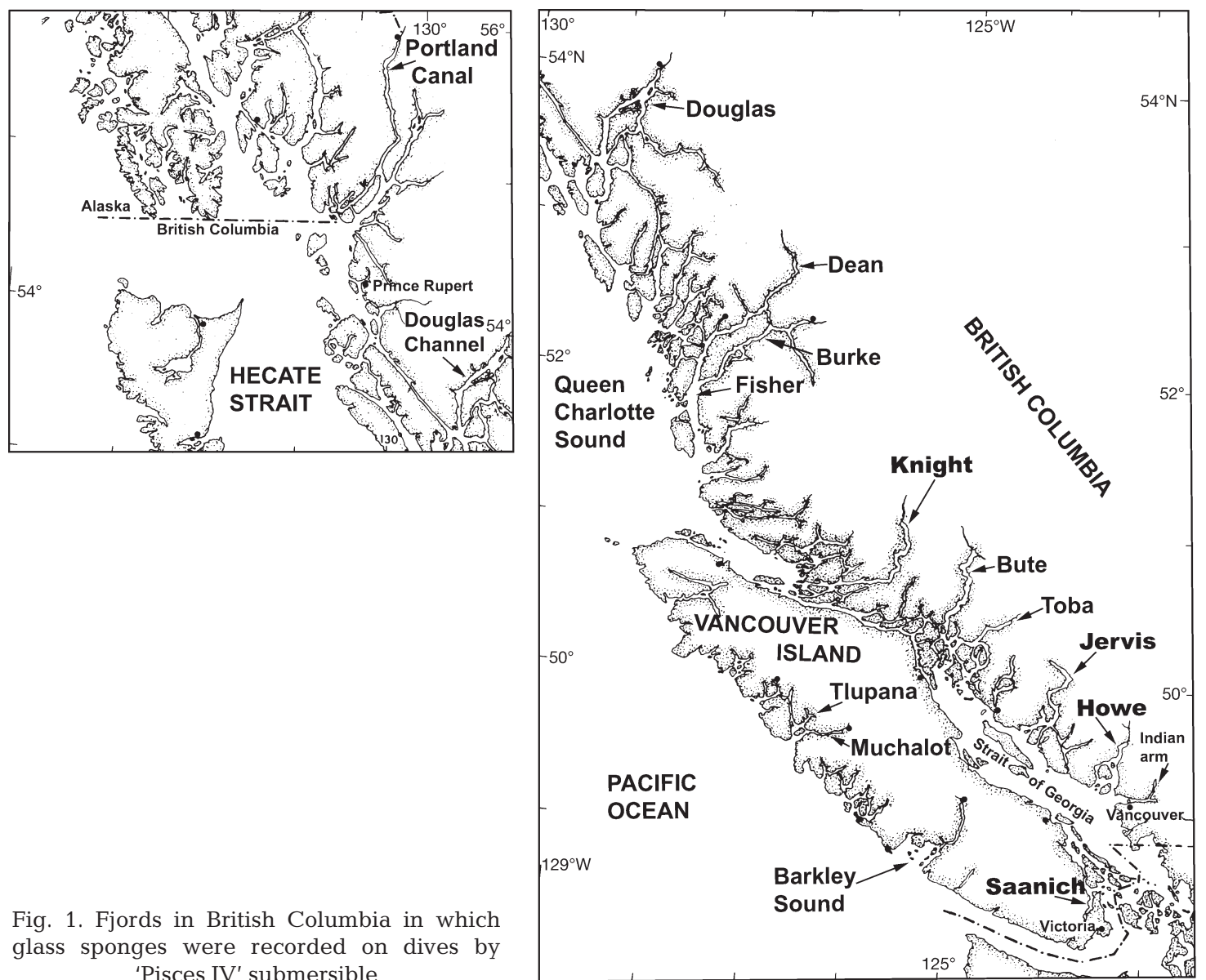

Fig. 1. Fjords in British Columbia in which glass sponges were recorded on dives by 'Pisces IV' submersible

Oceanographic setting and location of dive sites. Canada's Pacific coast is indented with several hundred fjords. Some exceed $700 \mathrm{~m}$ in depth and most have one or several shallow sills at the entrance that restrict water circulation. The isolated fjord waters have temperatures and salinities that vary little over many years (Pickard 1963); the deeper regions of some fjords can be anoxic for much of the year. Dives were carried out at sites in all the fjords listed in Table 1. The locations of dive sites in each of Jervis Inlet, Knight Inlet, Howe Sound and Saanich Inlet are shown in Fig. 2 together with profiles of each inlet. Oceanographic characteristics of each inlet are summarized in Table 2.

Jervis Inlet is the deepest fjord on the coast, and consists of a series of basins 350 to $680 \mathrm{~m}^{1}$ deep separated by low sills (Fig. 2A). An annual mean freshwater input of $180 \mathrm{~m}^{3} \mathrm{~s}^{-1}$ from numerous small rivers causes a weak estuarine circulation with a net seaward movement

\footnotetext{
${ }^{1}$ Record from 'Pisces' dives. Canadian hydrographic charts show maximum depths in Jervis Inlet as $659 \mathrm{~m}$. The difference is presumed to be due to method of measurement and tide height.
}

of surface water and inflow at depth (Pickard 1961, Timothy \& Soon 2001). In both Jervis and Saanich Inlets, lithic materials dominate the suspended load during winter months, and plankton (mainly diatoms) is the primary component of sediment during summer months (Sancetta 1989).

Knight Inlet is the most northerly inlet assessed in detail (Fig. 2B). An outer sill lies at $60 \mathrm{~m}$, and a shallow inner sill at $48 \mathrm{~m}$ borders an inner basin with a maximum depth of $550 \mathrm{~m}$. Freshwater input entering from the Klinaklini River at the head of the inlet is at a maximum in June from melting snow and ice at higher altitudes. There is a net outflow of surface water, due in part to the low salinity water from the river and in part to strong outflow winds, but significant currents occur throughout the water column (Pickard \& Rodgers 1959). Rates of sedimentation (mostly lithic particles from glacial meltwater) are highest near the head of the inlet year-round and in the surface waters during summer months (Farrow et al. 1983).

Howe Sound lies north of Vancouver (Fig. 2C). The northern arm of the outer sound forms 2 basins enclosed by a sill at $110 \mathrm{~m}_{i}$ the southern arm provides a 200 m-deep direct connection with Georgia Strait 
Table 1. Observations from 'Pisces IV' submersible dive records of glass sponges in British Columbia fjords and adjacent waters (sh: shallowest; dp: deepest). Fjord locations are shown in Fig. 1. (Abbr. = location abbreviation). Depths in normal font: from dive transcripts; depths in italics: from photographic records; depths in parentheses: dead sponges; -: no sponge recorded. Source (diver): diver who recorded data, where $1=\mathrm{V}$. Tunnicliffe; $2=\mathrm{W}$. C. Austin; $3=\mathrm{H}$. M. Reiswig

\begin{tabular}{|c|c|c|c|c|c|c|c|c|c|c|}
\hline \multirow{2}{*}{$\begin{array}{l}\text { Inlet } \\
\text { Dive location }\end{array}$} & \multirow[t]{2}{*}{ Abbr. } & \multirow{2}{*}{$\begin{array}{l}\text { ‘Pisces' } \\
\text { Dive No. }\end{array}$} & \multirow[t]{2}{*}{ Date } & \multirow[b]{2}{*}{$\min }$. & \multirow[b]{2}{*}{$\max }$. & \multicolumn{2}{|c|}{$\begin{array}{c}\text { - Depth (m) } \\
\text { Lyssacine }\end{array}$} & \multicolumn{2}{|c|}{ Dictyonine } & Source \\
\hline & & & & & & $\begin{array}{l}\text { Lys } \\
\text { sh }\end{array}$ & $\begin{array}{l}\text { cine } \\
\text { dp }\end{array}$ & $\begin{array}{l}\text { Dic } \\
\text { sh }\end{array}$ & $\begin{array}{l}\text { yonine } \\
\mathrm{dp}\end{array}$ & (diver) \\
\hline Saanich & $\mathbf{S}$ & & & & & & & & & \\
\hline Finlayson Arm & SF & 1017 & 25 Mar 81 & 7 & 131 & 35 & 65 & 56 & $(129)$ & 1 \\
\hline Elbow Point & SE & 940 & 19 Nov 80 & 48 & 165 & 48 & - & - & 51 & 1 \\
\hline Elbow Point & $\mathrm{SE}$ & 1500 & 8 Aug 84 & 43 & 105 & 60 & 65 & - & 61 & 1 \\
\hline Elbow Point & $\mathrm{SE}$ & 1385 & 3 Nov 83 & 32 & 74 & 60 & 64 & 46 & $60 /(67)$ & 1 \\
\hline McCurdy Point & $\mathrm{SM}$ & 884 & 3 Sep 80 & 22 & 204 & 22 & 77 & 50 & 70 & 1 \\
\hline McCurdy Point & SM & 942 & 20 Nov 80 & 30 & 120 & 35 & 72 & 39 & 64 & 1 \\
\hline Senanus Island & SS & 1243 & 22 Mar 83 & 12 & 202 & 23 & 70 & $30^{\mathrm{a}}$ & $50 /(100)$ & 3 \\
\hline Dyer Rocks & SD & 1242 & 21 Mar 83 & 19 & 210 & 19 & 51 & - & - & 3 \\
\hline Indian Arm & I & & & & & & & & & \\
\hline Indian Arm & & 1398 & 21 Nov 83 & 25 & 200 & - & - & 95 & $125 /(126)$ & 2 \\
\hline Howe & $\mathbf{H}$ & & & & & & & & & \\
\hline Woodfibre & HW & 1575 & 15 Nov 84 & 30 & 202 & - & - & 38 & $132 /\left(175^{\mathrm{b}}\right)$ & 1 \\
\hline Minaty Bay & $\mathrm{HM}$ & 1009 & 17 Mar 81 & 24 & 275 & - & 270 & 24 & $194 /(250)$ & 1 \\
\hline Inner Basin & $\mathrm{HI}$ & 1217 & 2 Dec 82 & 38 & 258 & 80 & 120 & 38 & $150 /(258)$ & 1 \\
\hline Port Mellon & HP & 1011 & 19 Mar 81 & 25 & 224 & 170 & 200 & 140 & 222 & 1 \\
\hline Montague Channel & $\mathrm{HC}$ & 1013 & 19 Mar 81 & 150 & 237 & - & - & 150 & 213 & 1 \\
\hline Gambier I, Halkett Point & HG & 1234 & 14 Jan 83 & 40 & 203 & 46 & 62 & - & 62 & 2,3 \\
\hline E Bowyer Island & $\mathrm{HB}$ & 1233 & 14 Jan 83 & 16 & 205 & 17 & 92 & 18 & $92 /(128)$ & 2,3 \\
\hline N Lions Bay & HL & 1235 & 15 Jan 83 & 97 & 235 & 115 & 230 & 122 & 232 & 2,3 \\
\hline Jervis & $\mathbf{J}$ & & & & & & & & & \\
\hline Queen's Reach (Hill Rock) & JQ & 1219 & 3 Dec 82 & 30 & 325 & 40 & 325 & 150 & 352 & 1 \\
\hline Pat Point (Queen's Reach) & JP & 1573 & 13 Nov 84 & 20 & 511 & 20 & 380 & 32 & 481 & 2 \\
\hline Prince of Wales Reach, Killam Bay & y JW & 1574 & 14 Nov 84 & 20 & 663 & 19 & 369 & 36 & 512 & 2 \\
\hline Saumarez Bluff & JS & 1231 & 13 Jan 83 & 250 & 622 & 340 & 560 & 260 & 367 & 3 \\
\hline Miller Islet (near Dark Cove) & JD & 1783 & 2 Nov 86 & 68 & 497 & 161 & 233 & 70 & 497 & 2 \\
\hline Dark Cove (Foley Head) & JD & 1781 & 1 Nov 86 & 15 & 350 & 22 & 345 & 36 & - & 2 \\
\hline Dark Cove & JD & 849 & 19 May 80 & 33 & 680 & 39 & 650 & 33 & $500 /(680)$ & 1 \\
\hline Dark Cove II & JD & 989 & 23 Feb 81 & 31 & 600 & 130 & 640 & 23 & 590 & 1 \\
\hline Ball Point - $\mathrm{W}$ of $\mathrm{N}$ ferry terminal & $\mathrm{JB}$ & 1179 & 28 Oct 82 & 26 & 115 & 32 & 100 & 32 & 115 & 2,3 \\
\hline Ball Point (sill) & JB & 986 & 21 Feb 81 & 25 & 310 & 25 & 310 & 30 & 310 & 1,2 \\
\hline Toba & $\mathbf{T}$ & & & & & & & & & \\
\hline Homfray Channel & & 1225 & 6 Dec 82 & 50 & 733 & 78 & 500 & 78 & 693 & 2 \\
\hline Pendrell Sound & & 1226 & 7 Dec 82 & 32 & 280 & 32 & 280 & 32 & 280 & 2 \\
\hline Knight & $\mathbf{K}$ & & & & & & & & & \\
\hline Rubble Point & $\mathrm{KR}$ & 977 & 16 Feb 81 & 20 & 290 & - & - & - & 280 & 1 \\
\hline Mount Dundas & $\mathrm{KD}$ & 978 & 16 Feb 81 & 69 & 414 & 69 & 407 & 312 & 407 & 1 \\
\hline Tsukola Point & KT & 980 & 17 Feb 81 & 50 & 500 & 50 & 380 & 50 & 370 & 1 \\
\hline Naena Point & $\mathrm{KN}$ & 979 & 17 Feb 81 & 170 & 529 & 170 & 460 & - & 500 & 1 \\
\hline Tomastum Island & $\mathrm{KI}$ & 981 & 18 Feb 81 & 15 & 234 & 45 & 190 & 75 & $190 /(200)$ & 1 \\
\hline Sail Cone & $\mathrm{KC}$ & 974 & 13 Feb 81 & 25 & 260 & 30 & 140 & 125 & 260 & 1 \\
\hline Sill & KS & 976 & 14 Feb 81 & 67 & 74 & - & - & - & - & 1 \\
\hline Mt. Anthony (outside sill) & KA & 985 & 20 Feb 81 & 6 & 150 & 25 & 84 & 40 & 150 & 1 \\
\hline Central Coast & $\mathbf{C C}$ & & & & & & & & & \\
\hline Fitzhugh Sound, Calvert Island & & 1171 & 21 Oct 82 & 58 & 350 & 240 & 253 & 240 & 255 & 1 \\
\hline Cathedral Point, Burke Channel & & 1174 & 24 Oct 82 & 28 & 587 & 28 & 570 & 100 & 570 & $1,2,3$ \\
\hline Burke Channel sill & & 1178 & 27 Oct 82 & 25 & 92 & - & - & - & 50 & $1,2,3$ \\
\hline Dean Channel (Eucott Bay) & & 1175 & 25 Oct 82 & 20 & 336 & 94 & 250 & 180 & 225 & 1,2 \\
\hline Salisbury Cove, Fisher Cove & & 1177 & 27 Oct 82 & 90 & 540 & 135 & 460 & 90 & 522 & 1,2 \\
\hline Portland Canal & $\mathbf{P}$ & & & & & & & & & \\
\hline Entrance to Nasoga Gulf & & 1373 & 24 Oct 83 & 20 & 227 & - & 100 & $(70)$ & $(80)$ & 2 \\
\hline Miner's Point & & 1374 & 25 Oct 83 & 19 & 391 & 120 & 130 & 100 & 160 & 2 \\
\hline Maple Bay & & 1375 & 25 Oct 83 & 20 & 212 & 72 & - & 59 & 64 & 2 \\
\hline Stopford Point & & 1376 & 26 Oct 83 & 15 & 340 & - & 180 & 120 & 190 & 2 \\
\hline Stick Point & & 1377 & 26 Oct 83 & 12 & 288 & 35 & - & 22 & $40 /(90)$ & 2 \\
\hline Carr Point & & 1379 & 27 Oct 83 & 20 & 120 & - & 110 & 95 & - & 2 \\
\hline Richardson Point & & 1380 & 28 Oct 83 & 30 & 540 & 50 & - & 30 & 260 & 2 \\
\hline Truro Island & & 1382 & 30 Oct 83 & 10 & 560 & 120 & 520 & $(110)$ & 320 & 2 \\
\hline Barkley Sound & B & & & & & & & & & \\
\hline Pochantus Point & & 1564 & 1 Nov 84 & 16 & 270 & 25 & 172 & 46 & 265 & 2 \\
\hline Self Point & & 1755B & 31 Aug 86 & 7 & 117 & 80 & 96 & 52 & 96 & 2 \\
\hline Trevor Channel & & $1757 \mathrm{~B}$ & 2 Sep 86 & 17 & 127 & 44 & 50 & - & 85 & 2 \\
\hline SE Flemming Island & & 1756B & 1 Sep 86 & 12 & 124 & 67 & 73 & - & - & 2 \\
\hline Chupp Point, Alberni inlet & & 1473 & 23 May 84 & 100 & 255 & 80 & 217 & 126 & 179 & 2 \\
\hline Sprout Narrowa, Alberni inlet & & 1563 & 1 Nov 84 & 18 & 141 & 35 & 38 & - & - & 2 \\
\hline Mid Effingham inlet & & 1472 & 23 May 84 & 14 & 255 & 70 & 217 & 126 & 179 & 2 \\
\hline $\begin{array}{l}\text { Muchalot } \\
\text { Near McCurdy Creek }\end{array}$ & $\mathbf{M}$ & 1275 & 3 May 83 & 13 & 360 & 16 & 160 & 130 & $170 /(287)$ & 2 \\
\hline Tiupana & Ti & & & & & & & & & \\
\hline Princess Royal Point & & 1276 & 3 May 83 & 17 & 232 & 16 & 187 & 80 & 187 & 2 \\
\hline
\end{tabular}


A
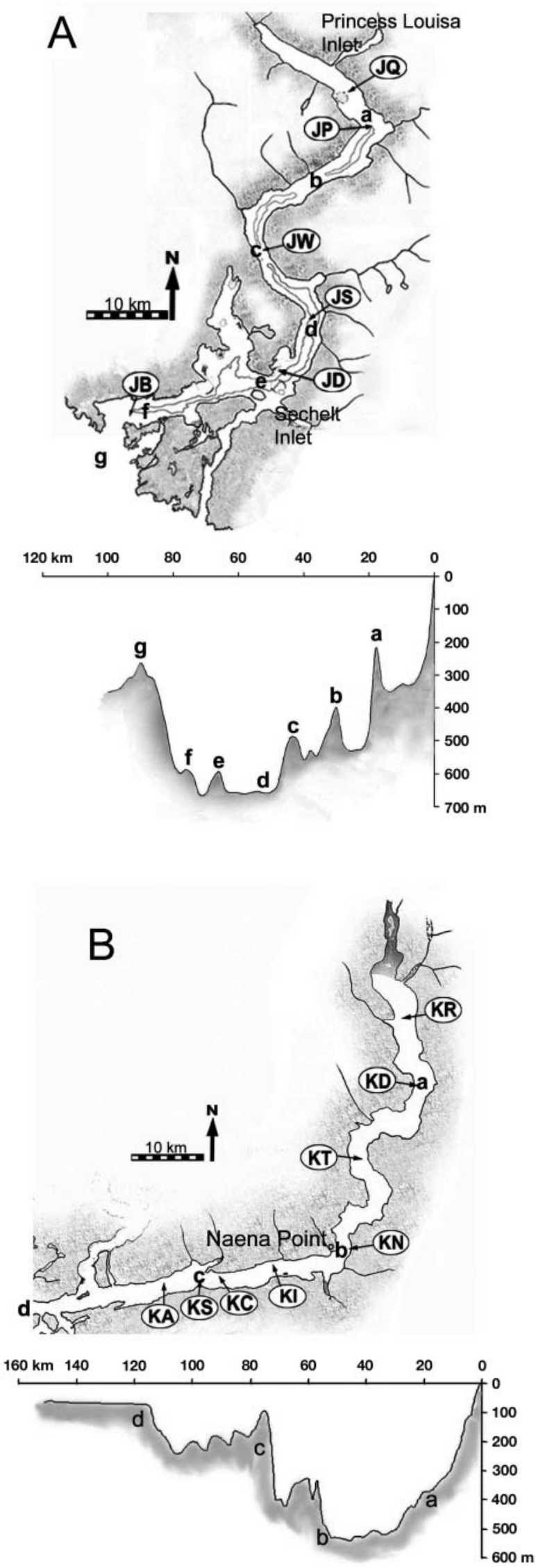
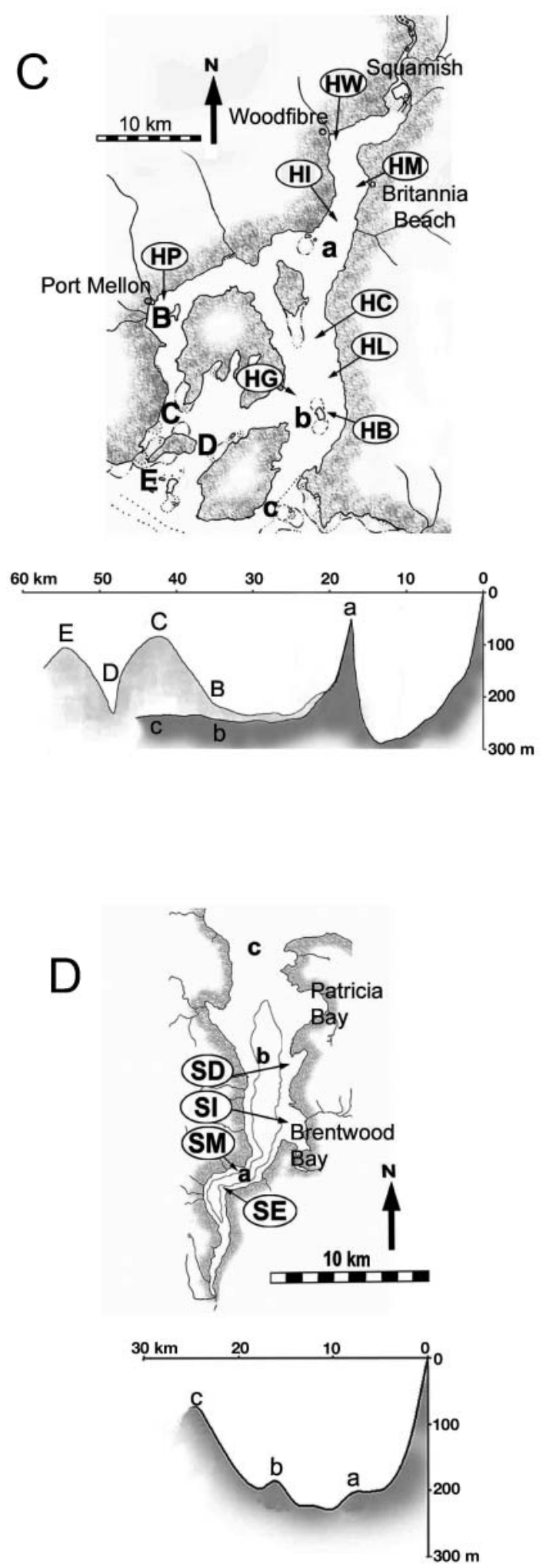

Fig. 2. Locations of dive sites in the 4 principal fjords studied, and profiles of each fjord; abbreviations in Table 1. (A) Jervis Inlet; (B) Knight Inlet; (C) Howe Sound; (D) Saanich Inlet. $\mathrm{a}-\mathrm{g}$ : specific locations on profile of each fjord 
Table 2. Oceanographic characteristics of principal fjords studied

\begin{tabular}{|lcccc|}
\hline Parameter & Jervis Inlet & Knight Inlet & Howe Sound & Saanich Inlet \\
\hline Length (km) & 89 & 102 & 44 & 24 \\
Width (mean, km) & 3.1 & 3 & 7 & 3.5 \\
Depth (m) & 495 & 420 & 225 & 200 \\
Mean mid-inlet & 670 & 540 & 285 & 225 \\
Max. & 240 & 64 & 110 & 70 \\
Outer sill & 219 & 48 & 300 & 3 \\
Inner sill & 180 & 410 & $1-5$ & $10-15$ \\
Freshwater input $\left(\mathrm{m}^{3} \mathrm{~s}^{-2}\right)$ & negl. & $5-75$ & Sycitski \& Macdonald (1982) & Stucchi \& Giovando (1984) \\
Tidal currents $\left(\mathrm{cm} \mathrm{s}^{-1}\right)$ & Pickard (1961) & Pickard \& Rodgers (1959) & Stucchi (2002) \\
Source & Stucchi (2002) & Stucchi (2002) & Stucchi (2002) \\
\end{tabular}

(Syvitski \& Macdonald 1982). The Squamish River, at the head of Howe Sound, has a mean annual discharge of $300 \mathrm{~m}^{3} \mathrm{~s}^{-1}$, but discharges from summer snow-melts are typically twice that amount, and the winter flow is only $100 \mathrm{~m}^{3} \mathrm{~s}^{-1}$ (Hickin 1989). Currents are driven by tides, katabatic winds, and freshwater discharge from the Squamish River, and are low throughout the sound with the highest velocities occurring at the surface (Syvitski \& Macdonald 1982). Sedimentation is largely a result of glacial meltwater brought in by the Squamish River (Syvitski \& Macdonald 1982, Hickin 1989, McLaren et al. 1993).

Saanich Inlet, on Vancouver Island (Fig. 2D), does not have a significant source of freshwater input along

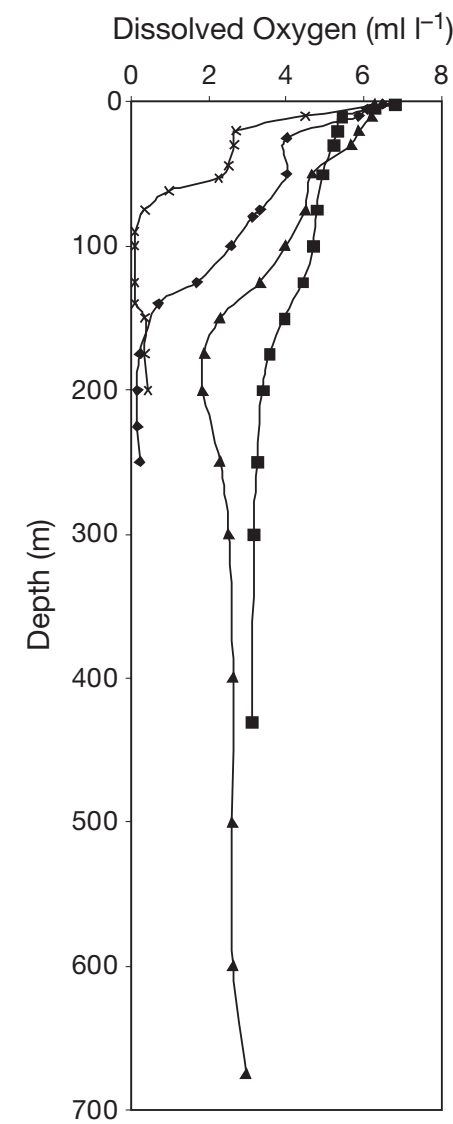

Transmissivity $\left(\% \mathrm{~m}^{-1}\right)$

$$
\text { Silicates }\left(\mu \mathrm{mol} \mathrm{I}{ }^{-1}\right)
$$
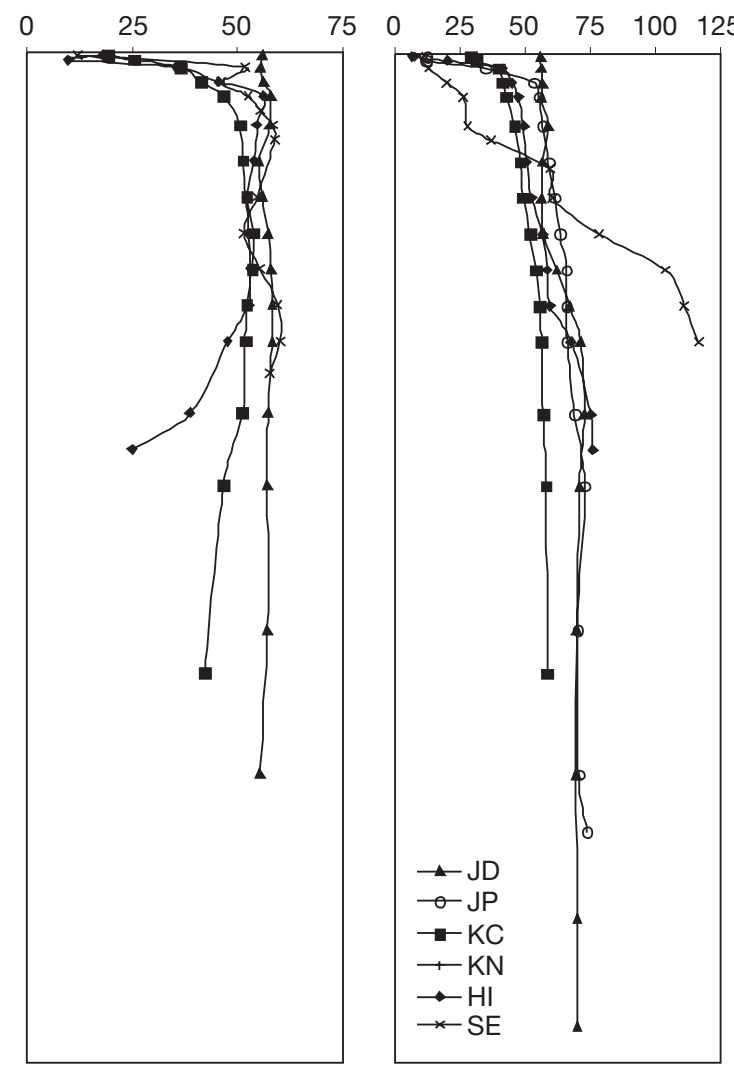

Temperature $\left({ }^{\circ} \mathrm{C}\right)$

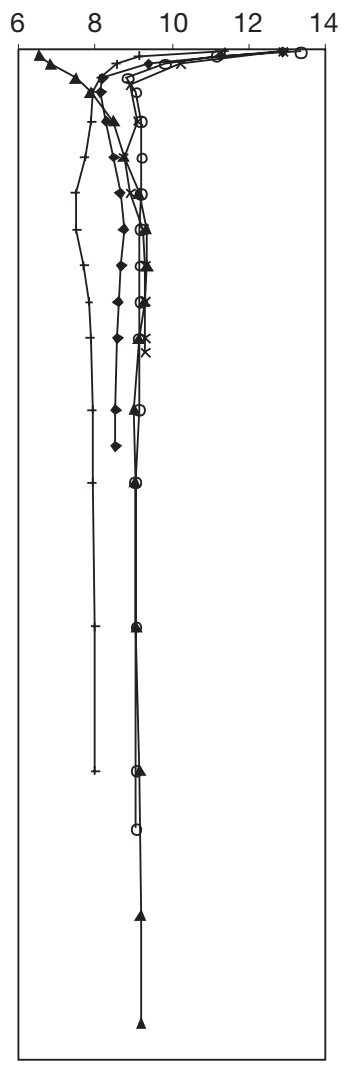

Fig. 3. Water characteristics of each of the 4 principal fjords studied; location abbreviations in Table 1. All samples at Location JD were collected on January 28, 2002, all samples at Location KC on May 24, 2003. Samples at other locations were collected as follows: Oxygen-SE May 23, 1980 Dive 921; HI December 2, 1982 Dive 1217. Transmissivity-SE May 29, 2001 ; HI May 25, 2002. Silicates-SE May 29, 2001; HI May 25, 2002; JP May 28, 2002. Temperature-SE May 27, 2003; HI May 25, 2002; JP May 25, 2002; 
its shores, but it does receive substantial estuarine water from a river just outside the fjord mouth. The lack of strong tidal currents, outflow winds, or significant estuarine circulation results in very little exchange of water in the inlet (Herlinveaux 1962), creating a region below $100 \mathrm{~m}$ that is anoxic for the greater part of the year (Tunnicliffe 1981). The deepbasin renewal is an annual fall event triggered by bottom-water movement in the adjoining straits (Tunnicliffe 1981, Stucchi \& Giovando 1984). Large diatom blooms occur in the spring (Sancetta 1989).

Water characteristics. We examined 4 factors that may influence the vertical distribution of sponges: dissolved oxygen, water clarity, silicate concentrations and temperature. Data were made available by the Department of Fisheries and Oceans (Ocean Science and Productivity: fjord program) from surface cruises in 2002 and 2003. The exception is the oxygen measurements in Saanich Inlet and Howe Sound which were those taken during the dives on which sponges were observed in 1980 (Saanich, Stn SE) and 1982 (Howe Sound, Stn HI). Water samples were taken during the cliff ascents by drawing water through a port in the submersible. Analysis was by the modified micro-Winkler technique to detect low oxygen.

The dissolved oxygen profiles in Fig. 3 represent minimum values from the profiles examined. In the case of Saanich Inlet, concentrations below $1 \mathrm{ml} \mathrm{l}^{-1}$ persisted for $2 \mathrm{mo}$ in the fall of 1980 deeper than $60 \mathrm{~m}$, a phenomenon that is usually an annual occurrence. In the observation year, inner Howe also had little oxygen below $140 \mathrm{~m}$. The oxygen minimum in Jervis between 100 and $300 \mathrm{~m}$ was more pronounced near the head of the inlet (than those at Dark Cove shown in the graph), where profiles taken in May and December included values below $1 \mathrm{ml} \mathrm{l}^{-1}$.

The water clarity profiles reflect the spring plankton blooms in the upper layers of Saanich Inlet, Howe Sound and Knight Inlet. The greater particulate load measured at depth in inner Howe Sound was confirmed by submersible observations of turbid water and sediment-coated sponges. The Knight profile, however, precedes the time of heavy glacier melt in June (no data available) and probably does not reflect peak sediment loading.

In late spring, silicate concentrations in the top $20 \mathrm{~m}$ of all inlets are notably lower than values in deeper water; in February, surface silicate values are between 50 and $60 \mu \mathrm{mol} \mathrm{l}^{-1}$. Jervis silicate concentrations probably stay over $50 \mathrm{\mu mol} \mathrm{l}^{-1}$ year-round below $25 \mathrm{~m}$ depth. In Saanich Inlet, silicate depletion can extend as deep as $60 \mathrm{~m}$ although the shape of the profile differs from spring to spring. The sharp rise in silica at depth recorded in Saanich may have been due to diatom accumulation in low-oxygen water.
The temperature profiles reveal a thermocline at about $25 \mathrm{~m}$ in all fjords. Average temperatures at $\geq 50 \mathrm{~m}$ in Jervis and Saanich Inlets were over $9^{\circ} \mathrm{C}$ in May but markedly lower in Howe and Knight. In January, temperatures in Saanich dropped below $9^{\circ} \mathrm{C}$ while temperatures in Jervis remained stable.

\section{RESULTS}

\section{Description of species}

In shallow (less than $500 \mathrm{~m}$ ) coastal waters of British Columbia, 9 species of hexactinellid sponge occur. All are in the subclass Hexasterophora, a group distinguished by the presence of a type of small spicule, the hexaster (Hooper \& Van Soest 2002). The main species of interest were originally described from Döderlein's Japan collection by Schulze (1899) and Dawson's Vancouver Island collections by Lambe $(1893,1894)$. More extensive species descriptions and earliest data on species distributions of this region were made by Schulze (1899) from the 1888 to 1897 USFCS 'Albatross' collections.

In this hexactinellid subclass, 2 groupings are readily recognizable: one has a skeleton of fused spicules (dictyonine), the other a skeleton that is loosely held together by tissue strands (lyssacine); 6 species are lyssacine hexactinellids in the order Lyssacinosida, families Rossellidae and Leucopsacidae, and 3 species are dictyonine hexactinellids in the order Hexactinosida, families Aphrocallistidae and Farreidae.

Observers on the 'Pisces' dives reported 3 dictyonine sponges, Aphrocallistes vastus Schulze, 1886, Heterochone calyx (Schulze, 1887), and Farrea occa Bowerbank, 1862, and 4 lyssaccine sponges, Rhabdocalyptus dawsoni (Lambe, 1893), Staurocalyptus dowlingi (Lambe, 1894), S. solidus Schulze, 1899 and Acanthascus cf. platei, 1899. The shape of A. vastus can vary greatly (Fig. 4A,B). It frequently forms large (up to $1.5 \mathrm{~m}$ long) funnels with palm (or mitten)-shaped side processes (Fig. 4B). The principal osculum is at the end of the funnel but other oscula may occur at the tips of some, but not all, of the palm-shaped processes. The sponge is attached at the base by a plate-like almost solid glass skeleton. Other individuals can form massive branching bush-like structures, in which the palm-shaped processes are more tubular, and oscula occur throughout the sponge at the ends of nearly all branches (Fig. 4A: inset). In the Strait of Georgia, A. vastus can form tubes with no side-processes (http://mareco.org/khoyatan/spongegardens). Although H. calyx often forms funnels (Fig. 4C), it can also grow in bush-like clumps (Fig. 4D). In most individuals, the side processes form tubes rather than flat palm-shaped 


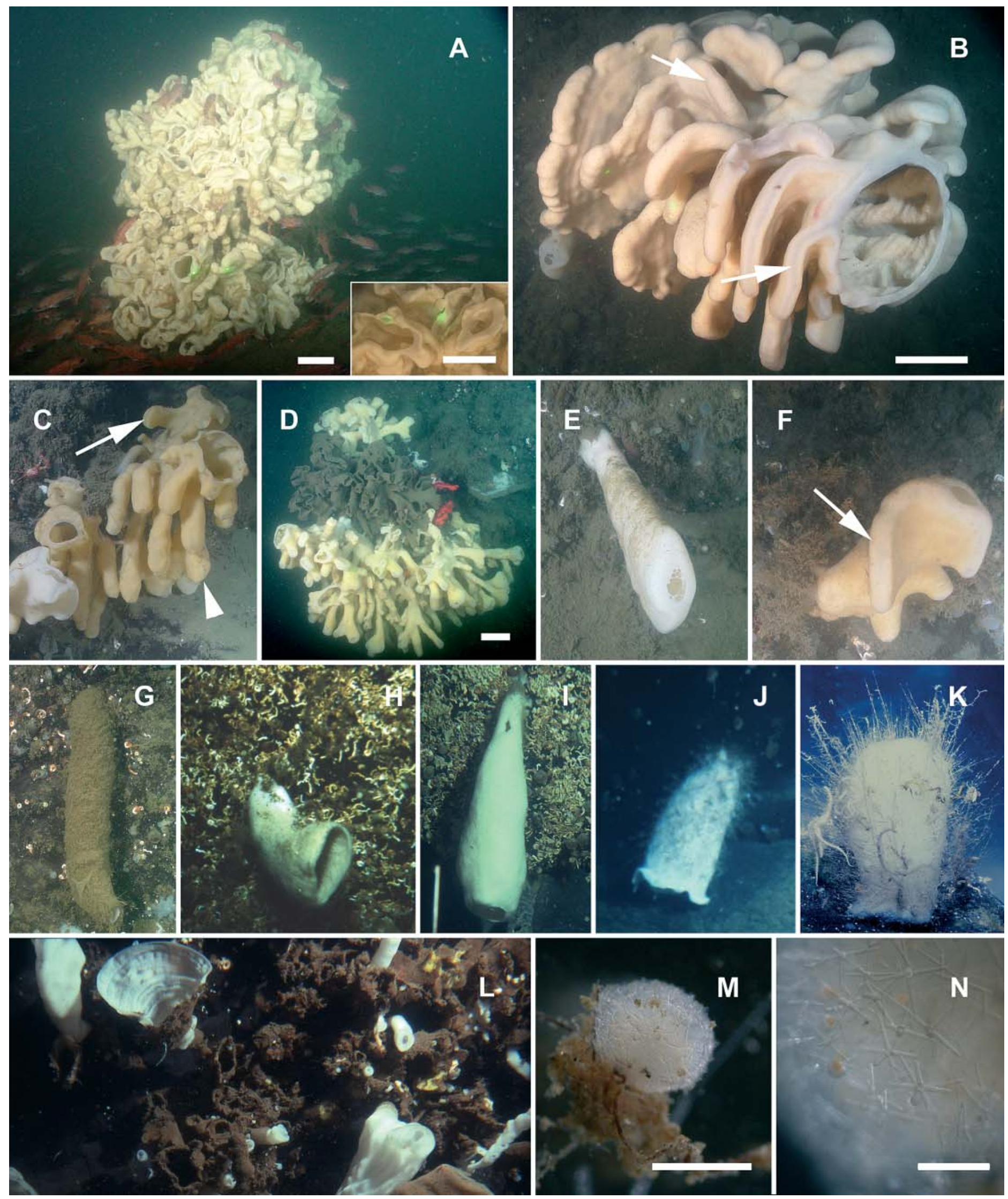


Fig. 4. Images of glass sponges identified without samples (i.e. visually) from the 'Pisces IV' submersible and remotely operated vehicle ROPOS. (A-F) dictyonine sponges; $(\mathrm{G}-\mathrm{K})$ lyssacine sponges; (L-N) dictyonine skeletons and juvenile sponges. (A) and (B) are both presumed to be Aphrocallistes vastus; inset in (A) shows 2 of the many tubular oscula; arrows in (B) indicate palm or mittenshaped processes extending from a single oscular tube. (C) and (D) are both presumed to be Heterochone calyx; (C) shows tube form with a single osculum, (D) shows bush form with multiple oscula; arrowhead in C points to tubular process considered typical of Heterochone spp., arrow points to palm-shaped process from same sponge. (E) and (F) juvenile dictyonine sponges without (E) and with ( $\mathrm{F}$, arrow) side processes. (G) Rhabdocalyptus dawsoni hanging with osculum facing down and away from cliff wall. (H) and (I) are both presumed to be Staurocalyptus dowlingi. (J) Acanthascus sp. (K) Small specimen thought to be S. olidus. (L) Sponge graveyard. (M) Juvenile dictyonine sponge found on a piece of dictyonine skeleton. (N) High magnification of surface spicules of juvenile in (M). Scales (where known): $(A, B, D)$ scale bar $=10 \mathrm{~cm}_{i}(C)$ sponge = approximately $20 \mathrm{~cm}$ from base to osculum; $_{(\mathrm{D})}$ sponge $=$ approximately $40 \mathrm{~cm}$ in diameter; $(\mathrm{E}, \mathrm{F})$ juveniles $=$ approximately $10 \mathrm{~cm}$ long; (G) sponge about $50 \mathrm{~cm}$ long;

$(\mathrm{H}-\mathrm{K})$ sizes unknown; $(\mathrm{L})$ juveniles on skeletons = approximately $5 \mathrm{~cm}$ long; $(\mathrm{M})$ scale bar $=1 \mathrm{~mm} ;(\mathrm{N}) \mathrm{scale}$ bar $=0.25 \mathrm{~mm}$

projections, but we cannot exclude the possibility that some individuals have both tube and palm-shaped processes (Fig. 4C), and juveniles may or may not have distinguishable projections (Fig. 4E,F). Furthermore, both sponges can be in shades of white, creamy yellow or mustard orange. The source of the pigment remains to be explored. F. occa also forms bushes of tubes, but this species can usually be distinguished by the thinness $(1 \mathrm{~mm})$ and fragility of its body wall in comparison to that of the other thicker dictyonine sponges.

Observers noted that several of the lyssacine sponges were also difficult to distinguish. Rhabdocalyptus dawsoni and Staurocalyptus dowlingi both form long tubes that can be coated with brown debris (Fig. $4 \mathrm{G}$ to I). Both hang down on vertical walls, and can bend up at the osculum in the shape of a boot. On horizontal surfaces both can form broad vases, with a widely flaring osculum and occasional buds at the base. There is little to distinguish these 2 sponges at the macroscopic level except that $S$. dowlingi has a smooth or rounded oscular lip compared with the sharp, spicule-fringed oscular lip of R. dawsoni (Austin \& Ott 1987). Acanthascus sp. cf. platei and $S$. solidus are also vase-shaped (Fig. 4J,K). These sponges differ from the other lyssacine sponges in lacking a debris-laden outer spicule coat. A. cf. platei may have tufts of spicules on the outer surface, giving it a cactus-like appearance, although these were not always apparent in photographs.

Skeletons of dictyonine sponges (Fig. 4L) host numerous other organisms, including juvenile hexactinellids (Fig. 4M,N).

\section{Coastal distribution of hexactinellid sponges}

The presence and depth distribution of dictyonine and lyssacine sponges in several inlets of the British Columbia coast are shown in Table 1. Distributions worth noting for each inlet are: Both lyssacine and dictyonine sponges were found in all the listed fjords with the exception of Indian Arm, from which lyssacine sponges appeared to be absent. However, among the dictyonine sponges, Farrea occa was observed only in the channels and fjords north of Vancouver Island (Fisher, Dean and Burke Channels) and Portland Canal; it is also an important component of the northern sponge reefs (Conway et al. 1991).

Both types of sponges occurred to the maximum depths of the fjord walls in Jervis, Toba and Knight Inlets and the inlets of the central and northern coasts, but lyssacine sponges were absent from the sills in Knight Inlet and Burke Channel. Both types were absent below certain depths in Howe Sound, Indian Arm, Effingham Inlet, Muchalot Inlet and Saanich Inlet; however, dictyonine sponge skeletons were found in some of these fjords at depths from 30 to $100 \mathrm{~m}$ below living glass sponges. Records for Howe Sound and Portland Canal show dictyonine sponges extending into relatively shallow water; the shallowest 'Pisces' records for lyssacine sponges are in Muchalot and Tlupana Inlets, and for dictyonine sponges are in Howe Sound.

\section{Sightings}

Observations of both lyssacine and dictyonine sponges and of skeletons of dictyonine sponges at each of the dive sites in the 4 inlets assessed in detail are shown in Fig. 5. Dictyonine sponges were observed in all 4 inlets, but were most commonly sighted on dives in Jervis Inlet and Howe Sound, frequently at depths less than $100 \mathrm{~m}$. The deepest occurrence of dictyonine sponges was $590 \mathrm{~m}$ at Dark Cove in Jervis Inlet; the shallowest occurrence reported by 'Pisces' dives was at $18 \mathrm{~m}$ in Howe Sound. Sightings of dictyonine sponges were least common on dives in Knight Inlet. At the head of Knight Inlet, dictyonine sponges were rare or absent (e.g. KR: 'Pisces' Dive 977; KD: 'Pisces' Dive 978; KN: 'Pisces' Dive 979).

Lyssacine sponges were seen in all inlets but were more commonly sighted in Saanich Inlet and Jervis Inlet, than in Howe Sound. In Howe Sound, no lyssacine sponges were seen at Woodfibre ('Pisces' Dive 
A Dictyonine sponges Jervis Knight Howe Saanich

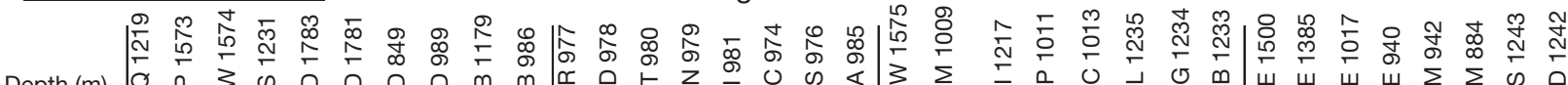

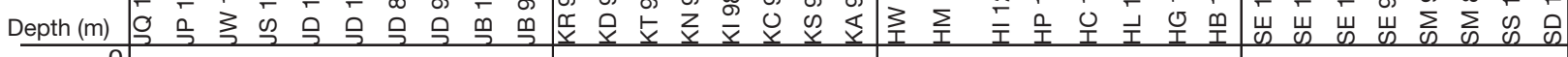

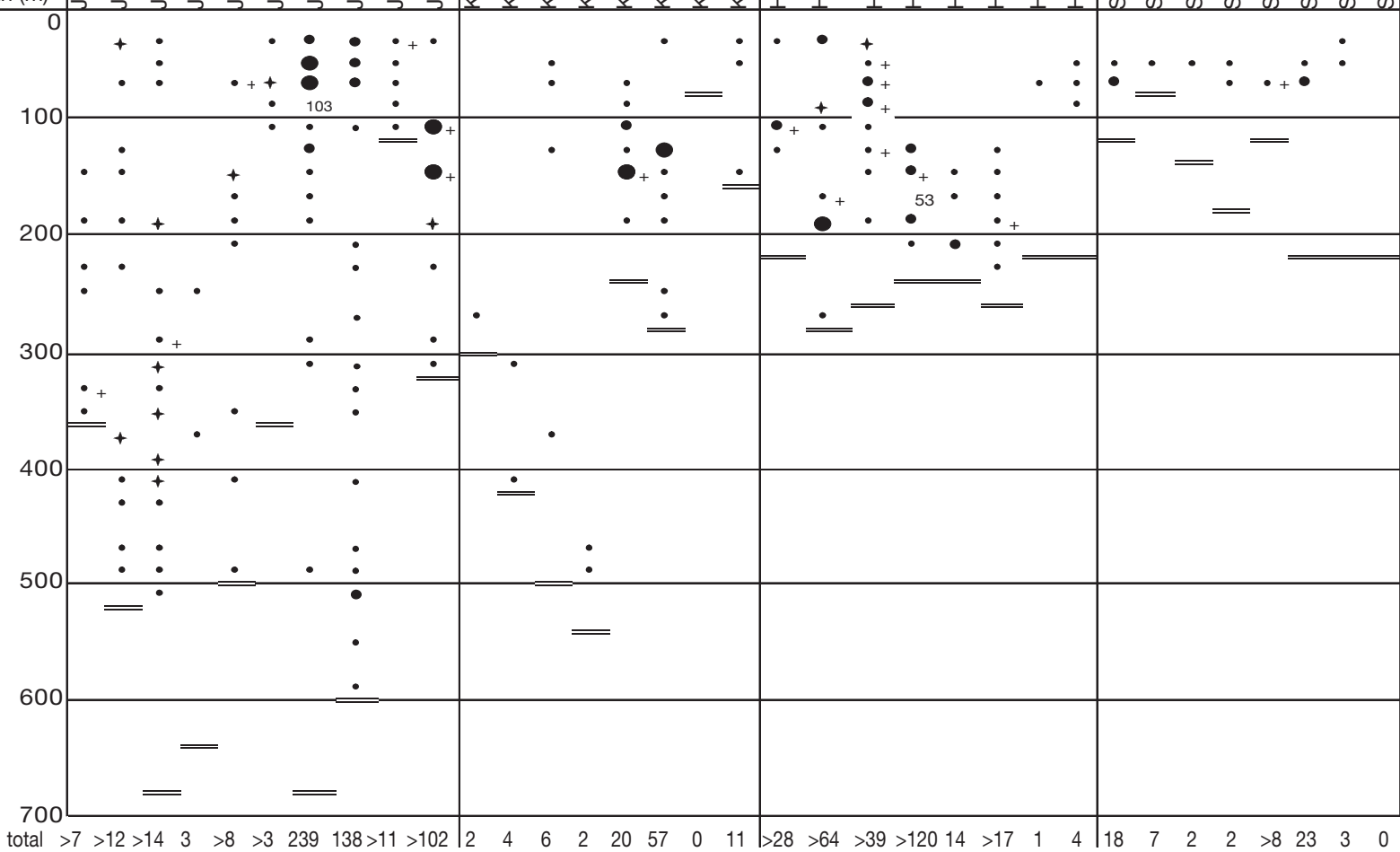

\section{B Lyssacine sponges}

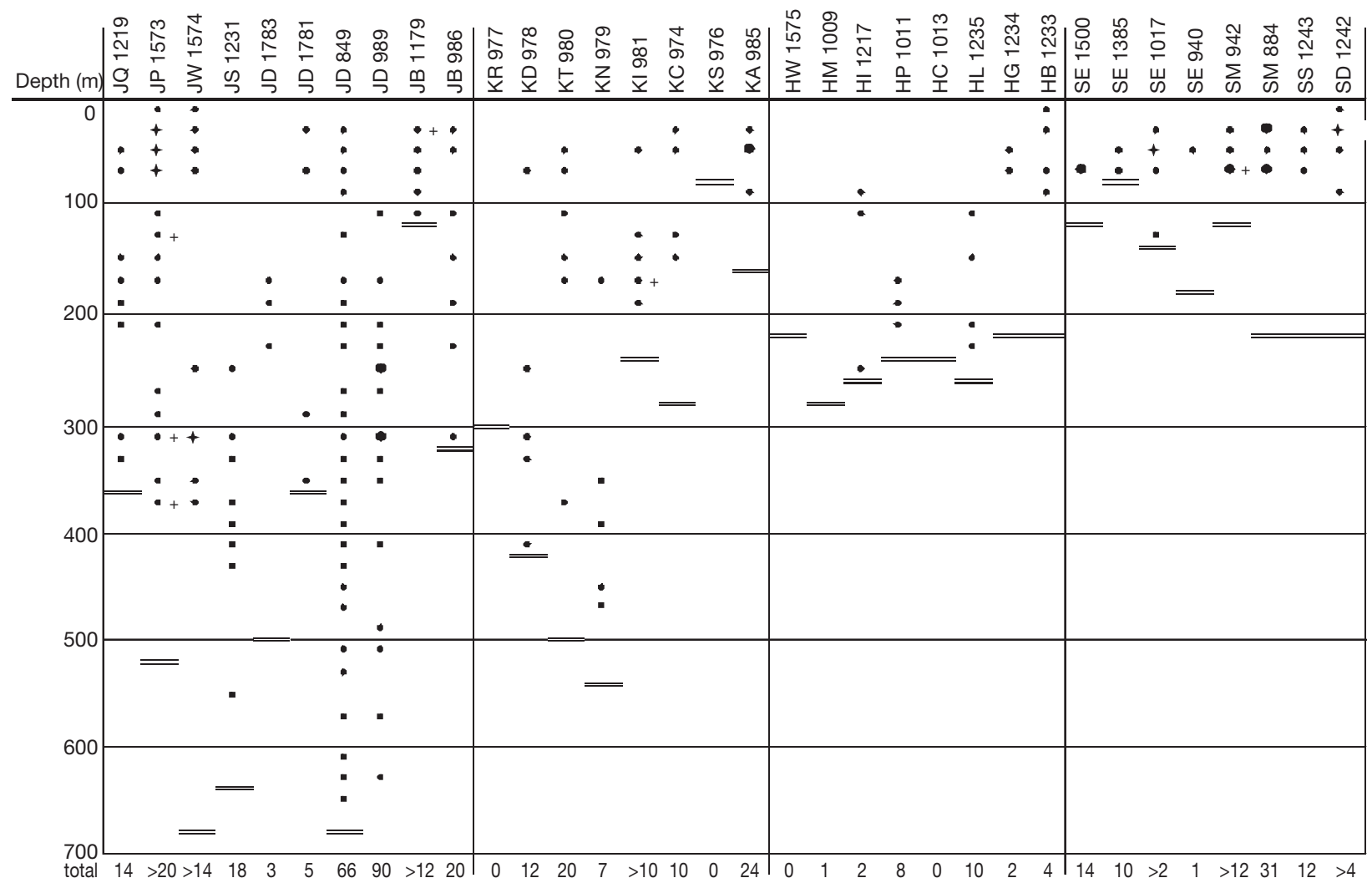




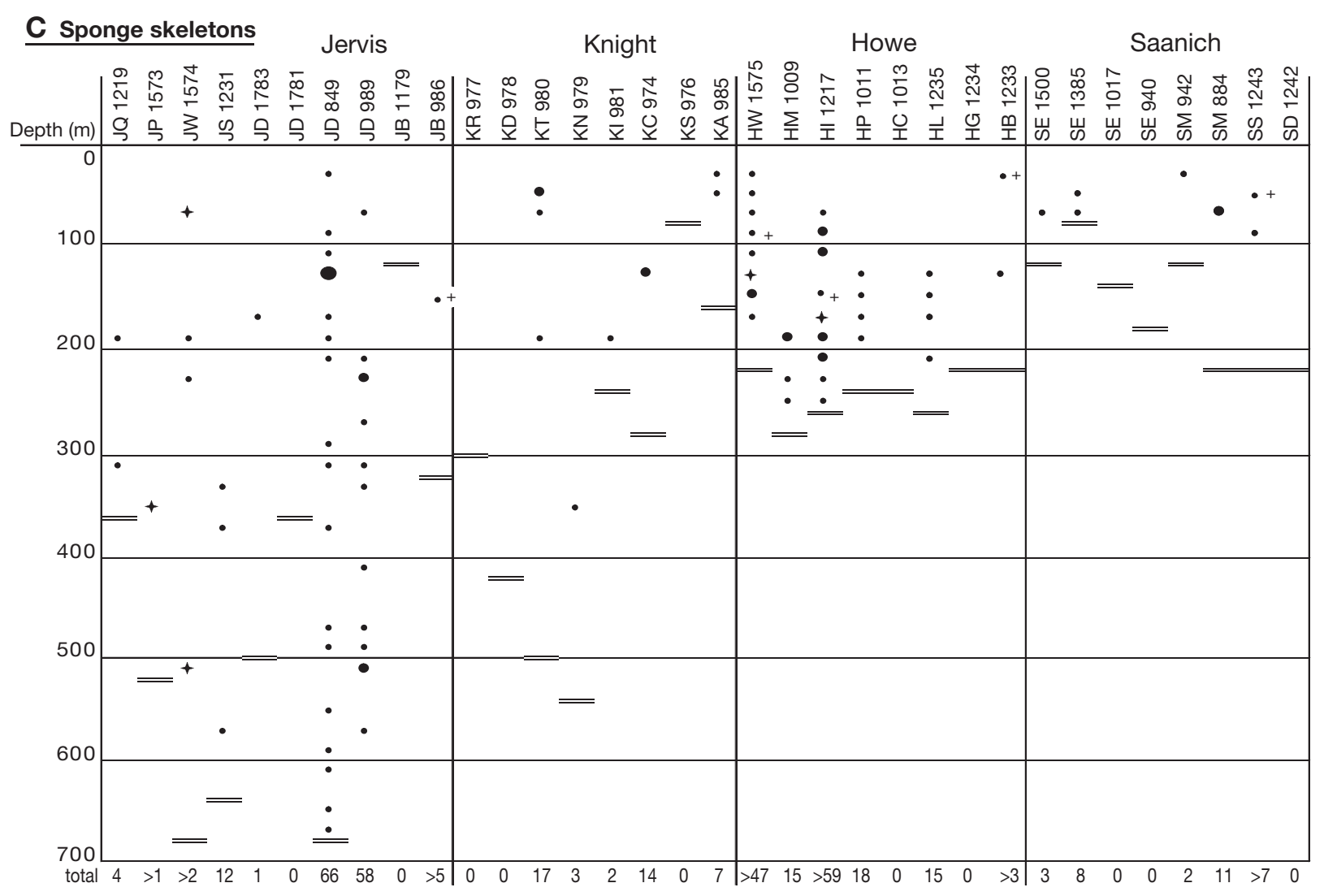

Fig. 5 (opposite and above). Sightings of (A) dictyonine sponges, (B) lyssacine sponges, and (C) sponge skeletons, from transcripts and photographs from all dives in the 4 main inlets studied. Dive locations in Table 1 arranged from left to right from head to mouth of each inlet. Short, double, horizontal lines indicate maximum depth of each dive. Circles indicate numbers of sponges every $20 \mathrm{~m}$; small circles: 1-10; medium circles: 11-30; large circles: 31-50; exact numbers are given for sightings of $>50$ sponges. (+) depths at which sponges were too abundant for individuals to be counted separately. Total number of sponges seen on each dive is given at bottom of each column

1575), only 1 'very dirty' sponge was reported at the deepest point at Minalty Bay ('Pisces' Dive 1009), and only 3 sponges were seen during the Inner Basin dive ('Pisces' Dive 1217), but divers commented that these sponges appeared to be dead. Lyssacine sponges were found at slightly shallower depths (up to $20 \mathrm{~m}$ ) than dictyonine sponges in Saanich and Jervis Inlets.

Large numbers of dead dictyonine skeletons were reported on dives in Howe Sound, with more than 60 skeletons seen between 160 and $220 \mathrm{~m}$ at the Inner Basin site ('Pisces' Dive 1217) and over 50 skeletons between 80 and $140 \mathrm{~m}$ at Woodfibre ('Pisces' Dive 1575). Dive transcripts from the Inner basin note that at $248 \mathrm{~m}$ there 'had been high glass sponge density'. Every photograph from $155 \mathrm{~m}$ to $235 \mathrm{~m}$ shows dead skeletons and some photographs have such a huge 'mass' of skeletons that individuals cannot be separated. Whereas dead sponge skeletons were noted at nearly all depths at Dark Cove ('Pisces' Dive 849) in Jervis Inlet, in Howe Sound most skeletons were observed in the deeper portions of the dive.

\section{Density of glass sponges in Saanich Inlet, Howe Sound and Jervis Inlet}

The densities of lyssacine and dictyonine sponges at 4 sites in Jervis Inlet, 4 in Howe Sound and 3 in Saanich Inlet are shown in Fig. 6. These dives were selected because they had the most complete photographic coverage for the entire depth of the dive.

Jervis Inlet had by far the greatest density of both lyssacine and dictyonine sponges, particularly at shallow depths (Fig. 6A). Dictyonine sponges were very abundant (up to 240 per $10 \mathrm{~m}^{2}$ ) at depths of 20 to $160 \mathrm{~m}$, and lyssacine sponges were most abundant (up to 53 per $10 \mathrm{~m}^{2}$ ) at depths of 120 to $240 \mathrm{~m}$. Although the bulk of the dictyonine sponges in shallow waters were in the smallest size class, there were more medium and large dictyonine sponges in shallow waters than at depths greater than $160 \mathrm{~m}$. The average number of dead dictyonine sponges was no greater in shallow or deeper water. Approximately equal numbers of small and medium-sized lyssacine sponges occurred at all 

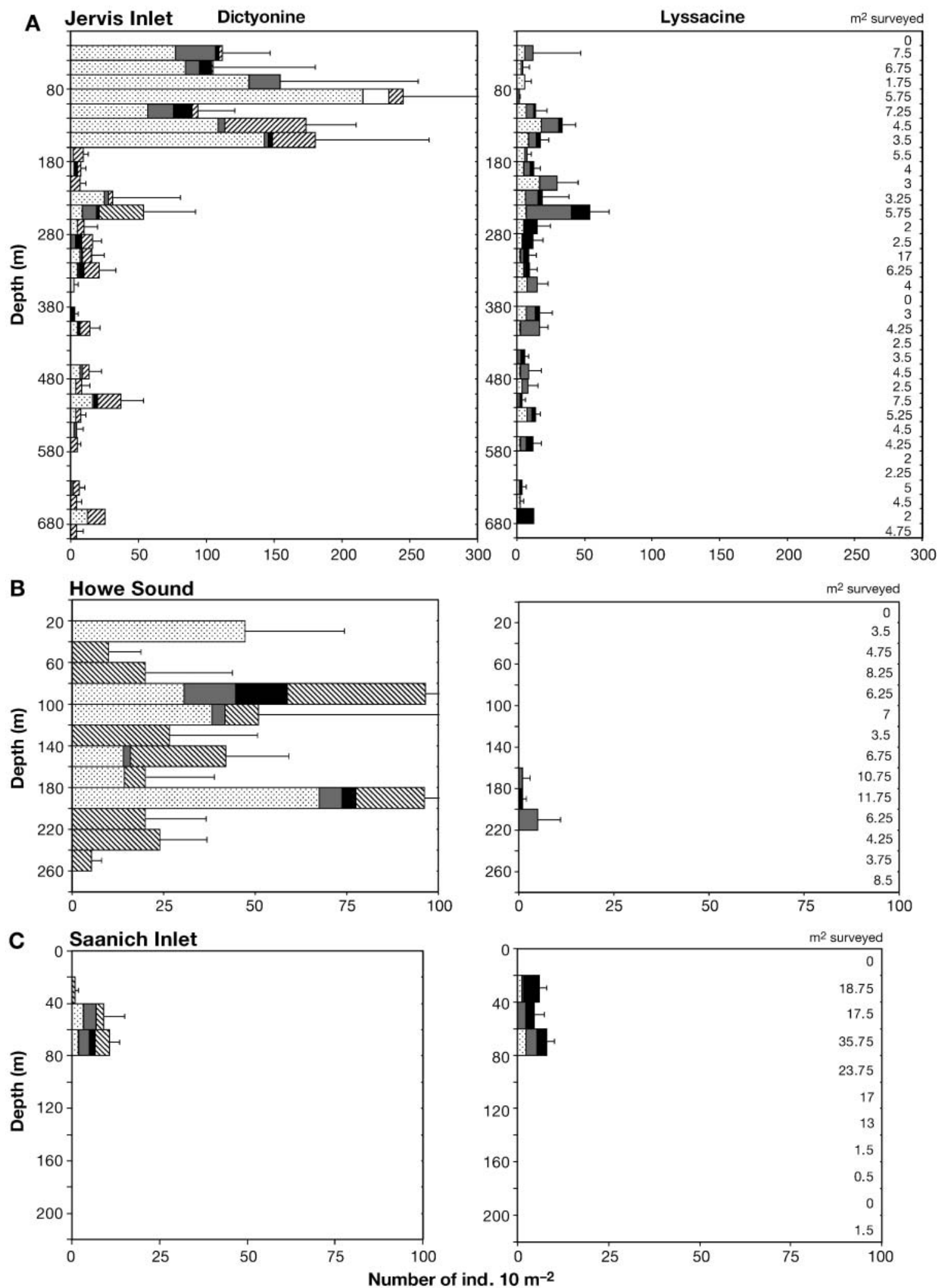

Fig. 6. Density of sponges at 4 sites in each of Jervis Inlet (A) and Howe Sound (B) and 3 sites in Saanich Inlet (C). Bars: average number of sponges recorded in photographs over $20 \mathrm{~m}$ depth intervals; averages are weighted to account for area of each photograph. Total area surveyed at each depth interval is given on right ordinate. $\mathbb{Z}:$ small sponges; $\square$ : medium sponges; $\mathbf{\square}$ : large sponges; $\mathbb{Z}$ : dead sponges (see 'Materials and methods' for details); error bars: SE 

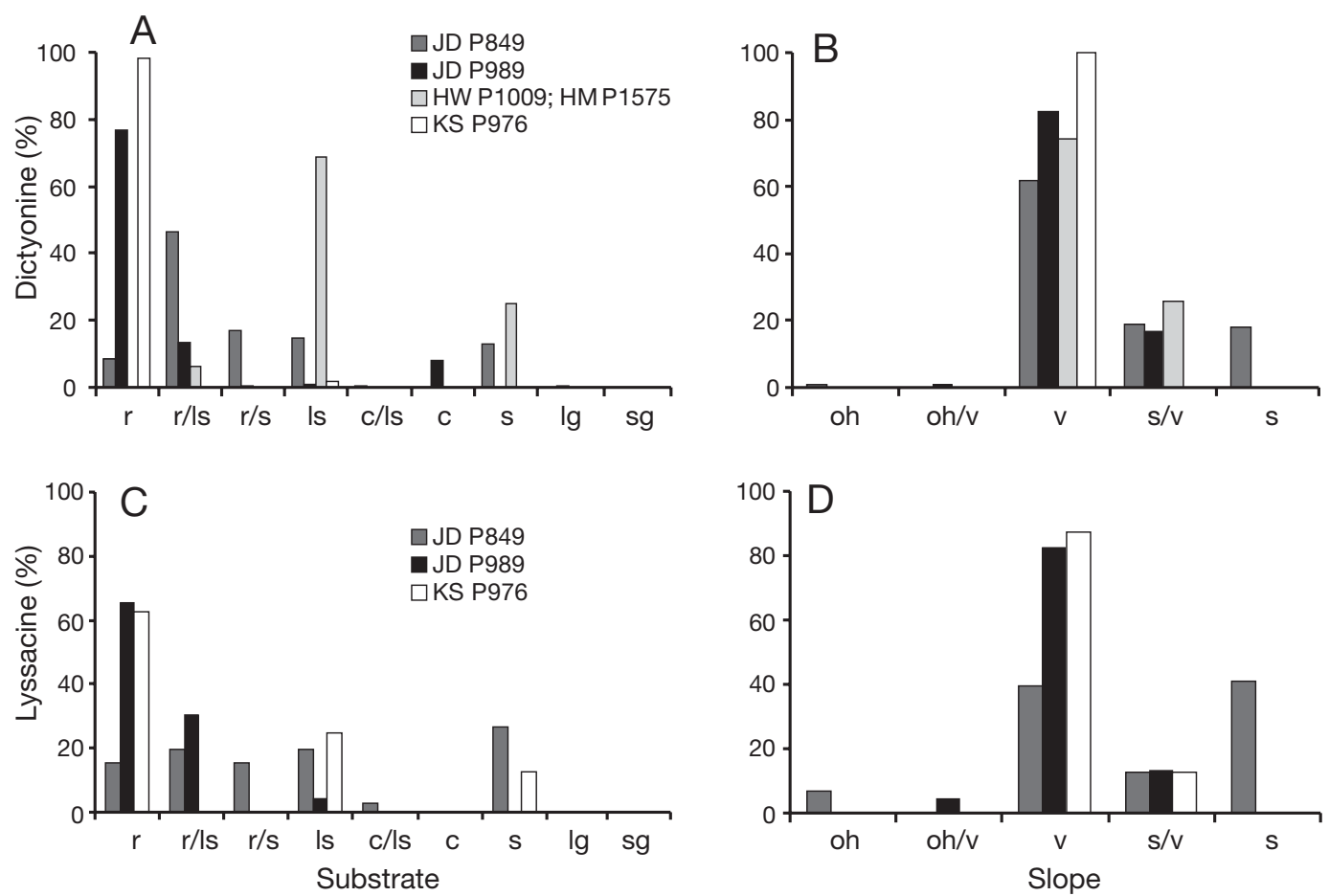

Fig. 7. Distribution of glass sponges on different substrates and slopes. (A,B) Dictyonine sponges; $(\mathrm{C}, \mathrm{D})$ lyssacine sponges; $(A, C)$ substrate; $(B, D)$ slope. Dive abbreviations in key as in Table 1. For substrates, r: rock; ls: light sediment; s: sediment; C: cobble; lg: light gravel; sg: sediment and gravel. For slopes, oh: overhang; v: vertical; s: sloped

depths at the 4 sites in Jervis Inlet, but the largest size class was not found shallower than $100 \mathrm{~m}$.

In Howe Sound, small dictyonine sponges were abundant between 20 and $200 \mathrm{~m}$ (up to 60 per $10 \mathrm{~m}^{2}$ ), but there were fewer live sponges in the larger size classes, and dead sponges were abundant at nearly all depths (Fig. 6B). Lyssacine sponges were scarce on all dives in Howe Sound with only 1 to 4 per $10 \mathrm{~m}^{2}$ between 160 and $200 \mathrm{~m}$.

Of the 3 inlets, Saanich Inlet had the lowest density of both types of hexactinellid sponge-fewer than 8 live sponges in $10 \mathrm{~m}^{2}$ (Fig. 6C). Hexactinellids in this inlet occur only between 20 and $70 \mathrm{~m}$ depth.

\section{Sponge distribution by slope and substrate}

Because it is difficult to determine the incline of the substrate from either still photographs or from video images, the photographic records of only 5 dives lent themselves to analysis of the distribution of sponges by slope; the same dives were used to determine the distribution of sponges by substrate. Most hexactinellids were observed on vertical or near-vertical walls, and on bare rock or on rock with only a light sediment cover (Fig. 7). Very few sponges, of either dictyonine or lyssacine morphologies, were found on what appeared to be gravel and sediment-covered substrates.

\section{DISCUSSION}

Glass sponges occur in all fjords examined, and were exceptionally abundant in some locations. Because glass sponges are large sessile animals, and are estimated to be fairly long-lived (Leys \& Lauzon 1998, Krautter et al. 2001), their patterns of distribution probably reflect long-term oceanographic characteristics of the fjord environments in the context of the physiological requirements of the different sponge species. Abundance differences both among fjords and with depth within fjords suggest that optimal conditions for sponge growth do not occur everywhere. Below, we discuss some possible factors that support the unusual densities of hexactinellids on the British Columbia coast and that determine distribution limits. This initial exploration of limiting factors requires substantiation by further observations and experimental work.

\section{Dissolved oxygen levels}

The lowest range of hexactinellids in Saanich Inlet is probably determined by the low oxygen levels that build every year. Deep-water renewal between August and November pushes very low oxygen water over the cliff benthos below $60 \mathrm{~m}$ depth (Herlinveaux 1962, Tunnicliffe 1981). In Saanich, the paucity 
of sponges in general and below $60 \mathrm{~m}$ in particular suggests that dissolved oxygen levels below $1 \mathrm{ml} \mathrm{l}^{-1}$ (Fig. 3) may pose one physiological limitation. However, the occurrence of bases of dictyonine skeletons at several sites in Saanich below $100 \mathrm{~m}$ suggests that, at some time in the past, Saanich Inlet was oxygenated to greater depths. Deep circulation into the inner Howe Sound is also restricted by a sill, but oxygen depletion is not always an annual event as it is in Saanich. Nevertheless, the dearth of lyssacine sponges and the abundance of sponge skeletons in the inner basin of Howe Sound is striking. In 1977 and 1978, anoxia was sustained for an anomalously long period (www-sci.pac.dfo-mpo.gc.ca/osap/projects/bcinlets/ default_e.htm) resulting in widespread death of fishes and invertebrates (Levings 1980). The massive graveyards of glass sponges reported on Pisces dives in the inner basin in 1981 could reflect this event. If so, then the many small live dictyonine sponges that were seen at 180 to $200 \mathrm{~m}$ at Minalty Bay in 1981 would have recruited after the low-oxygen event. Given the estimated rates of growth for lyssacine sponges (1 to $3 \mathrm{~cm} \mathrm{yr}^{-1}$; Leys \& Lauzon 1998), and dictyonine sponges ( 3 to $7 \mathrm{~cm} \mathrm{yr}^{-1}$; Krautter et al. 2001) it is quite possible that the sponges seen in the inner basin of Howe Sound in 1981 were no more than 3 to $4 \mathrm{yr}$ old. It is also likely that the juveniles recruited at the greatest depths did not survive the low oxygen levels encountered during the observation period (Fig. 3).

Divers in Jervis Inlet reported the greatest abundance of both kinds of sponges and the fewest dead sponges. The abundance of sponges was fairly uniform from head to mouth of the inlet, but there were significantly larger numbers of both kinds of sponges between 50 and $200 \mathrm{~m}$ although the walls extend to $600 \mathrm{~m}$ depth. There is an oxygen minimum at 150 to $300 \mathrm{~m}$ where waters are hypoxic $\left(<2 \mathrm{ml} \mathrm{l}^{-1}\right.$ oxygen) for much of the year (Levings et al. 1983).

\section{Sediment loading}

In the upper reaches of Knight inlet, a glacial-fed river carries a high sediment load into the inlet, with deposition rate decreasing down-inlet (Farrow et al. 1983). At Location KD (Fig. 2B), divers reported sponges to be small and 'dripping in mud' or 'sediment-covered'. While high suspended particulate loads probably affect all sponges adversely, experiments on Rhabdocalyptus dawsoni suggest that glass sponges may be particularly sensitive because intake of particulates causes cessation of the feeding current until the suspended material clears from the water (Leys et al. 1999). The shallow sill of Knight Inlet con- stricts tidal exchange and resultant currents may exceed $2.5 \mathrm{~m} \mathrm{~s}^{-1}$. Turbulence from internal waves generated at the sill is evident several kilometers upstream (Farmer \& Smith 1980), where suspensionfeeder populations on the cliffs are dense (Farrow et al. 1983). Here, sediment accumulation is minimal and glass sponges are present in greatest abundance at the upstream sites KC and KI (Fig. 2).

In contrast, deep-water exchange into Jervis Inlet is neither restricted nor accelerated at the mouth. There is little freshwater input into the fjord (Pickard \& Rodgers 1959, Pickard 1961, Timothy \& Soon 2001) and thus suspended sediment loads are relatively low. Comparison of the pattern of glass sponge distribution in Knight and Jervis Inlets suggests that high rates of sedimentation deter glass sponges from becoming established (Farrow et al. 1983).

\section{Dissolved silica}

No experimental data exist regarding the silica requirements of hexactinellids, but correlations between dissolved silica levels and glass sponge abundance world-wide suggest that they need high levels of dissolved silica (Austin 1984). Dissolved silica levels are high in both the Antarctic Ocean and coastal north east Pacific Ocean (Treguer et al. 1995, Timothy \& Soon 2001), both regions of high glass sponge abundance. Above $20 \mathrm{~m}$, late-spring silicate concentrations are lowered by diatom uptake (Fig. 3); this time of greatest plankton production may also be the time of greatest sponge growth. Silicate concentrations below 30 to $40 \mu \mathrm{mol} \mathrm{l}^{-1}$ may contribute to the upper depth limitation for glass sponge growth. In years of high diatom production, Saanich Inlet silicate levels can be low throughout the upper waters; hexactinellid abundance is also low in this inlet. Whitney et al. (2004) identified silicate levels over $40 \mu \mathrm{m}$ around sponge reef communities in Hecate Strait. They propose that seasonal upwelling replenishes silicate supplies to the reefs.

Recent analysis of the spicules from skeletons of 4 hexactinellids and 2 demosponges suggests that their silica content is very similar (Sandford 2003). Although little is known about the deposition of silica in hexactinellids, as the enzyme responsible for the uptake of silica by demosponge tissues is more active at higher silica concentrations (Krasko et al. 2000), it may be presumed that the same is true for glass sponges. Maldonado et al. (1999) have shown experimentally that higher levels of dissolved silica can allow demosponges to make spicules they would not otherwise produce. They suggested that silicic acid concentration in seawater may be a key determinant of the bathy- 
metric distribution of heavily silicified demosponges and hexactinellids. Since regions of high glass sponge abundance globally are also regions that have high levels of dissolved silicates, it is likely that glass sponges may require even higher silica concentrations than demosponges for activity of the enzyme and uptake of silica; nevertheless, further experimental work is required to substantiate this.

\section{Temperature}

Their requirement for cold water may be linked to the unusual ability of glass sponges to arrest their feeding current when irritated by silt or sediment in the water (Leys et al. 1999). Recovery from a stimulated arrest of pumping (an electric shock which mimics the effect of particulates irritating the sponge tissue) is temperature-dependent. The optimal temperature for a robust arrest and recovery response for lyssacine sponges collected from $160 \mathrm{~m}$ in Barkley Sound was 9 to $10^{\circ} \mathrm{C}$; sponges did not arrest their pumping upon stimulation if the temperature was $12^{\circ} \mathrm{C}$ or higher, and sponges stopped pumping completely when the temperatures dropped below $7^{\circ} \mathrm{C}$ (Leys et al. 2003). Of the inlets examined, Jervis Inlet below $50 \mathrm{~m}$ maintained temperatures closest to the 9 to $10^{\circ} \mathrm{C}$ optimum. But data accumulated since the 1930s show that the temperatures in all the fjords of the southern coast have increased by at least $1^{\circ} \mathrm{C}$ in the last 30 to $50 \mathrm{yr}$ (www. sci.pac.dfo-mpo.gc.ca/osap/projects/bcinlets/default_e. $\mathrm{htm})$. If further warming of the fjord waters occurs, glass sponges may be restricted to even deeper or more northerly waters.

\section{Light sensitivity}

The first concrete evidence that hexactinellids are sensitive to light lies in the discovery of a light-sensitive enzyme that is expressed strongest in the projecting new tissues of the dictyonine sponge Aphrocallistes vastus (Schroder et al. 2003). British Columbia waters are relatively opaque year-round, but light penetration is limited in spring and summer months due to surface plankton blooms and in winter by low light incidence angles when, in Jervis and Saanich Inlets, only $10 \%$ of surface light penetrates to $15 \mathrm{~m}$ (Sancetta 1989). While the shallowest lyssacine species (Rhabdocalyptus dawsoni) is covered in debris that could provide light protection, dictyonine hexactinellids are unprotected and have a deeper distribution throughout the coast. The one exception, a cloud sponge (A. vastus) at $5 \mathrm{~m}$ in Seymour Narrows (Austin 1999, 2003) lives deep in a crevice protected from light.

\section{Food availability}

Food availability is probably highest in the upper $200 \mathrm{~m}$ in the fjords. Limited information on glass sponge feeding suggests that lyssacine sponges may take up dissolved organic matter and that dictyonine glass sponges feed on bacteria (Reiswig 1990). Bacteria are abundant on phytodetritus (mostly diatoms) and fecal pellets that form the bulk of the 'sediment' in the southern inlets during summer months (Syvitski \& Macdonald 1982, Sancetta 1989). The peak abundance of gelatinous plankton observed on the Dark Cove transect in Jervis Inlet occurs at the same depth (Mackie 1985) as the sponge peak. It is likely that both organism groups find a high food density that may be linked: phytodetritus, zooplankton, bacteria and fecal pellets. In Saanich Inlet, large abundances of phytoplankton and zooplankton support high densities of other suspension feeders as well as glass sponges (Tunnicliffe 1981).

\section{Anthropogenic influences}

Howe Sound hosts 2 pulp and paper mills and a copper mine. During the early years of the pulp industry, dioxins and furans, byproducts of the bleaching process, built up in sediments. Their levels were highest in sediments within $2 \mathrm{~km}$ of Woodfibre (McLaren et al. 1993). The submersible dive $1 \mathrm{~km}$ northeast of Woodfibre (Fig. 2C) found thick flocculent material in the water column, a dusting of sediment on sunken logs, and sheet-like flocculated sediment suspended from dictyonine skeletons. Tailings dispersal from the Britannia copper mine are localized, with the highest copper levels (300 to $500 \mathrm{ppm}$ ) occurring at Britannia Beach and at the base of the inner sill (Syvitski \& Macdonald 1982). A more important factor may be increased sediment loading in the Squamish River from mining activities; the sponge graveyards lie at the base of the sill where river sediments accumulate (McLaren et al. 1993). The extensive sponge mortality recorded in this inlet may be related to smothering, oxygen deficits, toxic chemical effects or a combination of all factors.

\section{Substratum}

Although glass sponges can be found on sloped and vertical surfaces throughout coastal waters, the majority of substrates within the fjords are vertical walls with no sediments. In most fjords the cliffs are broken by substantial ledges that may have sediment and or gravel. Analysis of the distribution of sponges by slope 
and substrate showed that a few sponges of both morphologies were found on sediment-covered sloped substrates, but most were on vertical rock walls. Station JD, 'Pisces' Dive 849, is an exception, with equal numbers of lyssacine sponges on sloped and vertical surfaces. Here, dead skeletons that had accumulated on the ledges provided settlement substrate for live sponges. At the stations in Howe Sound more dictyonine sponges were found on sediment than on bare rock. Since all lyssacine sponges found in British Columbia fjords are believed to require a firm substratum for attachment, those sponges recorded on sediment must have been attached to boulders or rocks beneath the sediment. It is possible, however, that the sills are covered with too much silt to allow settlement of lyssacine sponges. Dictyonine sponges also require firm substrata to settle but, because they can settle on skeletons of other hexactinellids (Krautter et al. 2001) earlier generations which were able to establish themselves could have promoted the settlement of the sponges on sills recorded by 'Pisces' observers. This appears to be the case on Howe sill, which divers noted supports a small sponge 'reef'. Maldonado \& Young (1996) reported a similar pattern of preference for vertical rather than sloped substrates by demosponges on the Bahamian slope. They too concluded that sedimentation on shelves and horizontal surfaces could inhibit settlement of juveniles.

\section{Conditions for sponge growth}

British Columbia's fjords harbor an abundance of glass sponges, with maximum densities of reef-forming sponges of up to 240 per $10 \mathrm{~m}^{2}$ between 50 and $150 \mathrm{~m}$ in Jervis Inlet. This density of hexactinellids is not altogether unusual. Local abundances of hexactinellids are known from other shallow-water habitats. In the Weddell Sea, Antarctica, densities of hexactinellids at depths of 100 to $225 \mathrm{~m}$ reach 25 to 28 per $10 \mathrm{~m}^{2}$ (Barthel \& Gutt 1992), and in the Porcupine Seabight, NE Atlantic, Bett \& Rice (1992) reported monospecific expanses of glass sponges of up to 15 per $10 \mathrm{~m}^{2}$. The most dense community of glass sponges is that of Oopsacas minuta, a $6 \mathrm{~cm}$ long lyssacine sponge that inhabits submarine caves in the Mediterranean at densities of 1000 per $10 \mathrm{~m}^{2}$ (Vacelet et al. 1994). But, with the exception of $O$. minuta, glass sponges are large animals, often reaching over $1 \mathrm{~m}$ in diameter. This is certainly true of British Columbia's sponge populations.

What does distinguish British Columbia's sponge communities from those of other oceans is the abundance of reef-forming sponges. In Hecate and Georgia Straits, skeletons of dictyonine sponges become embedded in sediment over time, forming reef foundations
(Conway et al. 2001, Krautter et al. 2001). The situation in the fjords is not much different. Sediment fills the structure of the skeletons, coating the silica and presumably preventing erosion. It is not known how long these skeletons persist once coated, but the presence of bases of dictyonine sponges in the anoxic depths of Saanich Inlet suggests that they may persist for a very long time. The presence of juvenile sponges on the blackened, sediment-coated skeletons of Aphrocallistes vastus and Heterochone calyx shows that, like the sponge reefs, they can also nurse the growth of a new generation of sponges and, as such, create what 'Pisces' observers described as 'forests of sponges'.

The local oceanographic features of each of the fjords studied are sufficiently distinct to allow an understanding of the preferred conditions for glass sponge growth. The patterns of distribution and of local abundances of glass sponges in British Columbia's fjords appear to reflect the requirement of these sponges for high dissolved silica, low light levels and cold temperatures. The Jervis abundances suggest that hexactinellids prefer these conditions: dissolved oxygen over $2 \mathrm{ml}^{-1}$, low sedimentation rates, dissolved silica over $30 \mathrm{\mu mol} \mathrm{l}^{-1}$ in the spring, temperature between 9 and $10^{\circ} \mathrm{C}$, little to no light, and surfaces that do not accumulate sediments. Food availability in the growing season is likely to be a key factor as well. Further work on these apparent requirements is necessary.

Acknowledgements. This research was funded by the Natural Science and Engineering Research Council of Canada through V. Tunnicliffe, S. P. Leys, and H. M. Reiswig, and by Fisheries and Oceans Canada through H. M. Reiswig. We thank the officers and crew of the CCGS 'Pandora' and 'JP Tully', and the pilots of the 'Pisces IV' and 'ROPOS' for their support. A. M. Page provided technical assistance.

\section{LITERATURE CITED}

Austin WC (1984) Underwater birdwatching. Can Tech Rep Hydrogr Ocean Sci 38:83-89

Austin WC (1999) The relationship of silicate levels to the shallow water distribution of hexactinellids in British Columbia. Mem Queensl Mus 44:44

Austin WC (2003) Sponge gardens: a hidden treasure in British Columbia. www.mareco.org/khoyatan/spongegardens

Austin WC, Ott B (1987) Porifera. In: Kozloff EN (ed) Marine invertebrates of the Pacific Northwest, University of Washington, Seattle, p 6-31

Barthel D, Gutt J (1992) Sponge associations in the eastern Weddell Sea. Antarct Sci 4:137-150

Bett BJ, Rice AL (1992) The influence of hexactinellid sponge Pheronema carpenteri spicules on the patchy distribution of macrobenthos in the porcupine seabight (bathyl NE Atlantic). Ophelia 36:217-226

Conway KW, Barrie JV, Austin WC, Luternauer JL (1991) Holocene sponge bioherms on the western Canadian continental shelf. Contin Shelf Res 11:771-790 
Conway KW, Krautter M, Barrie JV, Neuweiller M (2001) Hexactinellid sponge reefs on the Canadian continental shelf: a unique 'living fossil'. Geosci Can 28:71-78

Farmer D, Smith J (1980) Tidal interaction of stratified flow with a sill in Knight Inlet. Deep-Sea Res A 27:239-246

Farrow GE, Syvitski JPM, Tunnicliffe V (1983) Suspended particulate loading on the macrobenthos in a highly tubid fjord: Knight Inlet, British Columbia. Can J Fish Aquat Sci 40:273-288

Ghiold J (1991) The sponges that spanned Europe. New Sci 2: $58-62$

Hall-Spencer J, Allain V, Fossa J (2002) Trawling damage to Northeast Atlantic ancient coral reefs. Proc R Soc Lond Ser B 269:507-511

Herlinveaux RH (1962) Oceanography of Saanich Inlet in Vancouver Island, British Columbia. J Fish Res Board Can 19:1-37

Hickin EJ (1989) Contemporary Squamish River sediment flux to Howe Sound, British Columbia. Can J Earth Sci 26: 1953-1963

Hooper JA, Van Soest RWM (eds) (2002) Systema Porifera. A guide to the classification of sponges, Vol 2, Plenum, New York

Husebø Å, Nøttestad L, Fosså JH, Furevik DM, Jørgensen SB (2002) Distribution and abundance of fish in deep-sea coral habitats. Hydrobiologia 471:91-99

Jamieson GS, Chew L (2002) Hexactinellid sponge reefs: areas of interest as marine protected areas in the north and central coast areas. DFO Canadian Science Advisory Secretariat Research Document 2002/122. www.dfompo.gc.ca/CSAS/Csas/English/Research_Years/2002/ 2002_122e.htm

Krasko A, Batel R, HC S, IM M, WEG M (2000) Expression of silicatein and collagen genes in the marine sponge Suberites domuncula is controlled by silicate and myotrophin. Eur J Biochem 267:4878-4887

Krautter M, Conway KW, Barrie JV, Neuweiller M (2001) Discovery of a 'living dinosaur': globally unique modern hexactinellid sponge reefs off British Columbia, Canada. Facies 44:265-282

Lambe LM (1893) On some sponges from the Pacific Coast of Canada and Behring Sea. Trans R Soc Can 10:67-78, pl III-VI

Lambe LM (1894) Sponges from the Pacific coast of Canada. Trans R Soc Can 11:23-43, pl II-IV

Levings CD (1980) Benthic biology of a dissolved oxygen deficiency event in Howe Sound, B.C. In: Freeland HJ, Farmer D, Levings CD (eds) Fjord oceanography. Plenum Press, New York, p 515-522

Levings CD, Foreman RE, Tunnicliffe VJ (1983) Review of the benthos of the Strait of Georgia and contiguous fjords. Can J Fish Aquat Sci 40:1120-1141

Leys SP (2003) The significance of syncytial tissues for the position of the Hexactinellida in the Metazoa. Integrative Comp Biol 43:19-27

Leys SP, Lauzon NRJ (1998) Hexactinellid sponge ecology: growth rates and seasonality in deep water sponges. J Exp Mar Biol Ecol 230:111-129

Leys SP, Mackie GO (1997) Electrical recording from a glass sponge. Nature 387:29-31

Leys SP, Mackie GO, Meech RW (1999) Impulse conduction in a sponge. J Exp Biol 202:1139-1150

Leys SP, Mackie G, Meech RW (2004) Effect of temperature on impulse conduction in the sponge, Rhabdocalyptus dawsoni. Proc Physiol Soc Cambr 555P: C-86

Mackie GO (1985) Midwater macroplankton of British Columbia studied by submersible PISCES IV. J Plankton
Res 7:753-777

Mackie GO, Singla CL (1983) Studies on hexactinellid sponges. I Histology of Rhabdocalyptus dawsoni (Lambe, 1873). Philos Trans R Soc Lond B 301:365-400

Maldonado M, Young CH (1996) Bathymetric patterns of sponge distribution on the Bahamian slope. Deep-Sea Res I 43:897-915

Maldonado M, Carmona MC, Uriz MJ, Cruzado A (1999) Decline in Mesozoic reef-building sponges explained by silicon limitation. Nature 401:785-788

McLaren P, Cretney WJ, Powys RL (1993) Sediment pathways in a British Columbia fjord and their relationship with particle-associated contaminants. J Coast Res 9:1026-1043

Müller WEG (2001) Review: How was the metazoan threshold crossed? The hypothetical Urmetazoa. Comp Biochem Physiol A 129:433-460

Pickard GL (1961) Oceanography of British Columbia mainland inlets. J Fish Res Board Can 18:907-999

Pickard GL (1963) Oceanographic characteristics of inlets of Vancouver Island, British Columbia. J Fish Res Board Can 20:1109-1142

Pickard GL, Rodgers K (1959) Current measurements in Knight Inlet, British Columbia. J Fish Res Board Can 16: 635-678

Reiswig HM (1979) Histology of hexactinellida (Porifera). Colloq Int Cent Natl Rech Sci 291:173-180

Reiswig HM (1990) In situ feeding in two shallow-water hexactinellid sponges. In: Rutzler K (ed) New perspectives in sponge biology. Smithsonian Institution Press, Washington, DC, p 504-510

Sancetta C (1989) Spatial and temporal trends of diatom flux in B.C. fjords. J Plankton Res 11:503-520

Sandford F (2003) Physical and chemical analysis of the siliceous skeletons in six sponges of two groups (Demospongiae and Hexactinellida). Microsc Res Tech 62:336-355

Schroder HC, Krasko A, Gundacker D, Leys SP, Muller IM, Muller WE (2003) Molecular and functional analysis of the (6-4) photolyase from the hexactinellid Aphrocallistes vastus. Biochim Biophys Acta 1651:41-49

Schulze FE (1899) Amerikanische Hexactinelliden nach dem materiale der Albatross-Expedition. Vol G, Fischer, Jena

Stucchi DJL (2002) Long term trends in deep water properties of BC inlets. Fisheries and Oceans Canada-Pacific region. www-sci.pac.dfo-mpo.gc.ca/osap/projects/bcinlets/ default_e.htm

Stucchi DJ, Giovando LF (1984) Deep water renewal in Saanich Inlet, B.C. Can Tech Rep Hydrogr Oceanogr Sci 38:7-15

Syvitski JPM, Macdonald RD (1982) Sediment character and provenance in a complex fjord; Howe Sound, British Columbia. Can J Earth Sci 19:1025-1044

Timothy DA, Soon MYS (2001) Primary production and deepwater oxygen content of two British Columbian fjords. Mar Chem 73:37-51

Treguer P, Nelson DM, Van Bennekom AJ, DeMaster DJ, Leynaert A, Queguiner B (1995) The silica balance in the world ocean: a reestimate. Science 268:375-379

Tunnicliffe V (1981) High species diversity and abundance of the epibenthic community in an oxygen-deficient basin. Nature 294:354-357

Vacelet J, Boury-Esnault N, Harmelin J (1994) Hexactinellid Cave, a unique deep-sea habitat in the scuba zone. DeepSea Res 41:965-973

Whitney F, Conway K, Thomson R, Barrie V, Krautter M, Mungov G (2004) Oceanographic habitat of sponge reefs on the Western Canadian continental shelf. Cont Shelf Res (in press) 